DOI 10.14746/ssp.2019.4.4

Emilia SMOLAK-LozAno

University of Malaga, Spain

ORCID: 0000-0001-8193-8786

\title{
Challenges and opportunities for digital convergence of TV: audience measurement in the digital era
}

\begin{abstract}
The research on television market and audience has been so far dominated by a telemetric system operating within a determined panel in the longitudinal manner. Nevertheless, the rise of digital era marked by the growing consumption of audiovisual content and TV in the Internet via VOD systems, subscription services, streaming etc. has changed the way the TV audience should be measured and tackled in order to deliver the significant data to advertisers. The digital services and therefore the online ads consumption are forcing the telemetric companies to re-design their methodology and measurement services. This thus requires not only new measurement methods and sample designs or research planning but also demonstrate new challenges and requirements starting from technical aspects and finishing on social and economic ones. Therefore, it is of great interests to find out how digital TV audience era is changing the way telemetric services are designed and conducted globally and at Polish market. The study attempts to find out how the TV audience measurement service is responding to the changes caused by digitalisation, which challenges and requirements have to be met in order to approach the issue of digitalisation of TV market in terms of the research planning and methodology. Finally, the present research pretend to determine and describe how the global market, and the Polish one in particular, perceives the services offered by Nielsen Audience Measurement. The research includes the series of individual semi-structured online individual interviews with managers and board of directors of the company as well as digital ads ratings department in Poland and headquarters in Switzerland. The results demonstrate the key changes, opportunities and challenges resulted from the digitalisation of TV consumption as perceived by management board, the company's strategy towards digital convergence and the estimation of the needs of new markets and audiences on the course of the digital transformation.
\end{abstract}

Key words: Television, TV audiences, telemetry, TV audience measurement, digital TV

\section{Introduction}

T $\mathrm{n}$ the media dominated ('mediatized') society, it is believed that it is the television that has the greatest significance amongst all 
mass media. It is due to such features as: free information flow, strong influence and wide access to latest information. In the contemporary world, the television has been subjected to the following processes: privatization (commercialization of entertainment industry that has created consumer market in the place of TV audience), individualization (creation of thematic channels and fragmentation together with specialization of TV audience) and globalization (perceiving TV as common good in literal sense which can be sold worldwide and kind of medium which can export and import worldwide products of television such as adverts and programs). The expansion into the Digital Era has only enforced those processes and characteristics of TV across countries.

Due to these processes, the Polish TV has changed its shape significantly by evolving towards Infotainment to adapt to the reality dominated by digital audiovisual content consumption. The data from the Polish market, as included in the main topic of the study ( $\mathrm{PwC}, 2017)$, confirms that video is the main format usually consumed online and the Internet is becoming the main source of entertainment for almost $50 \%$ of the Polish viewers, especially in the younger segments (so called Millenials). The mobile platform, Social Media and short free formats are preferred by the Polish TV audience. Simultaneously, the National Broadcasting Council in Poland confirms further digital revolution in the television as regards its technical aspects (2017-2022).

The viewing experience of the contemporary TV audience is becoming more multidimensional and multilaterally interactive. Infotainment that dominates both contemporary TV and digital content allows viewers to express their critical comments and remain active, but only within the genre and across multiple platforms, affecting the form of entertainment, information and journalism offered by TV stations. TV functioning and content has begun to reflect the taste and lifestyle of a more heterogeneous and digitalised TV auditorium and its consumption patterns (Szostak, 2012).

This function is the element of a wider TV business strategy, which is providing the demanded auditorium with particular ads from advertising companies (Ang I, 1991). The TV market uses viewership measurements performed amongst heterogeneous and dispersed TV audience, an audience which is differentiated demographically and flows fluently between channels and content (Abelman, Atkin, 2000, p. 75). 
The purpose is to develop the audience demanded by TV stations or advertisers. Telemetry helps to produce the final model of the TV audience's reaction towards TV programming: the size of audience and the extent to which the content is accepted by means of viewership data. Such measurements do not counterfeit the reality but its utility depends on the needs of the TV market and interpretation of indicators, although Ang (1991) criticizes telemetric research for producing an 'invisible fiction'. Telemetry maps these TV audiences' landscapes and factual data pertaining to real behaviour and choices made by the TV audience.

In the view of digitalisation and expanding digital consumption of video content and entertainment model based on online/Social Media/ mobile formats, the sector needs to review and expand measurement models to include the Internet statistics of audience into the metrics, even at the cost of a significant change in TV KPIs (Di Giorgio, 2017). The Big Data model based on multiple digital platforms requires solutions to be available for all types of broadcasters and advertisers and needs to contemplate the multi-platform, multi-format and trans-genre reality of TV consumption in the Digital Era. According to the 2018 IAB report, while referring to the fast growing digital market in Spain, highlighted the need to measure ad viewability to define the improvement of an average visibility level of digital communication on the market. As such, the IAB recognizes that the measurement technology industry and clients require some time to adapt both systems and processes to new standards and to start certification in accordance with well-established parameters (Raport Mobile, 2018).

The company selected for the study is the principal provider of audience data on 45 markets, Poland included. The Polish TV and media market is one of the largest and the most rapidly growing in East and Central Europe. In 2012, during the worldwide crisis and with the rising digital disruption, the Polish advertising spending was the third largest after Russia and Turkey), according to the ZenithOptimedia estimations in June 2012. ZenithOptimedia is also the first company to integrate the digital and Social Media data of content and audience into its audience metrics. As such, it is the main provider of telemetric data on the Polish media market. Therefore, it is of an utmost importance to examine the future of TV research and telemetry in general with global and European (Polish) perspective in terms of digitalization of content and video 
consumption, digital audiences' research and further expansion towards a digital model.

\section{The state of art}

Telemetry as a method used in social and communication applied research (Jensen, 2002) does not constitute a completely new topic, although it is not widely present in scientific literature. Despite of the criticism articulated by Ang (1991) towards this kind of research, a few publications have been published internationally and in Poland that reflect the use of the method in applied communication studies and on the TV market (Godzic, 2002; Sztabiński, Sztabiński, Sawiński, 2001; Ang, 1991, among others). Nevertheless, some recent critics echoes Ang's observations and accuse the TV for its lack of ability to measure and quantify the value (Kohn, 2017).

In general, over the years of the Social Media boom, the scientific output included numerous publications analysing the Social Media phenomenon in TV research and media studies. Regarding TV use, the dominating trend includes the impact of Social Media on viewing and consumption as reflected in bibliographic review of the scientific output on the topic (Segado, Grandío, Fernández-Gómez, 2013). Regarding the TV measurement, Baym (2013) has examined the use and disadvantages of Social Media metrics from a professional standpoint. The role of Social Media metrics in the classic telemetric measurement of the TV channel performance has also been occasionally present in scientific publications, such as the perspective of Social and Connected TV (Gallego, 2013). Additionally, a new approach to the modified TV audience measurement has developed as an attempt to trace viewing patterns on Twitter (van Es, van Geenen, Boeschoten, 2015).

However, Social TV metrics has been present in a limited way in overall communication and social research in the last 10 years. For example, the Web of Science (until 2013) includes only few publications (Segado, Grandío, Fernández-Gómez, 2013), and there are none on the Social Media metrics application in telemetry or the future of the digital TV and its measurement in scientific literature. Nevertheless, recently, professional publications from the industry have shown some concern 
of the future of the TV industry (DiGiorgio, 2017). The same applies to the lack of consensus from the TV industry on ratings innovation (Steinberg, 2017). Some authors, such as Green (Green, 2017) call directly for a better integration of digital video ratings into TV ratings since TV is changing so should the viewer metrics, according to C-Scott (C-Scott, 2015). Furthermore, the sociology of consumption or users' investigation (characteristics, customs, etc.) is the dominant perspective. The Szostak research (2012) was one of the initial and very few research projects trying to focus, on the one hand, on particularities of Polish TV broadcasters, TV fiction and private channels, and on the other hand, on the professional perspective from inside the sector (top management responsible for TV programme and production) in private media (private $\mathrm{TV})$. The present research attempts to follow the line but it focuses on the other side of the market: TV research providers rather than producers or broadcasters.

Given the overlooked section of the social and communication sciences regarding TV measurement in the digital era in present and future, the present study attempts to address the gap and provide a valuable and qualitative insight from professionals and practitioners in the sector.

\section{Definition of telemetry in TV research}

According to McQuail's theories described by Goban-Klas (1999), the auditorium has denominated the market, a market which is characterized by features of mainly behavioural and economic nature at the individual level. These are eventually aggregated in the form of TV auditorium or audience figures. This constitutes a preliminary consumer model of the auditorium (Mrozowski, 2001, p. 68).

By putting TV auditoria into the categories of market segments, it is simultaneously assumed that these segments behave as the consumers of commercial products. The activity of such described viewer-consumer is reflected in choosing particular titles and types of programmes and as well by TV watching habits measured post factum and displayed with the help of telemetric quantitative variables. Later, these markets become the objects of marketing strategies of TV broadcasters (Ettema, Whitney, 1993). 
Being a method of TV audience research, telemetry allows for a quantitative description of the TV audience by building statistical models or 'mapping of the TV audience' (Ang, 1991). Therefore, telemetry as the statistical method generalises viewership results for the population of viewers and for a telemetric sample during the viewership measurement. In case of Poland, the history of telemetric research started in 1996 with AGB Poland (now Nielsen Audience Measurement, NAM).

The technology of TV measurement in AGB Nielsen Media Research is the type of 'Peoplemeter measurement' dedicated to measure all modern TV services: digital TV, High Definition TV and Web or Internet TV, and it is defined as follows:

"The general methodology of gathering telemetric data (TAM) is based on the establishing of a telemetric sample according to the Establishment Survey (ES). It is a large-scale survey for collecting audience, demographic and other household data. The ES provides the basis for the determining of the population profile and target profiles based on selected panel control variables [...]. ES samples are also generally used as a source of addresses for the recruitment of the panel. The ES gathers demographic data and household data following trends in consumption (TV consumption as well). The ES research is based on the definition of a household which has not changed since 1996. [...] All the households participating in the telemetric panel have to have a TV set and receive a specific type of a TV signal. Moreover, the household audience has to watch the TV [...]. In telemetry, these type of households are called 'televiewing household units' (HUT) [...] Panel maintenance means all panel staff functions that preserve the panel balance over time and likewise accuracy of panel classifications and the quality of panel response by exercising periodical quality control procedures."

Some variables are related to the media-graphic behaviour of audiences, such as: Average Minute Rating, Average Time Viewed, Average Time Spent or Audience Share \%. Apart from audience data, there are variables related to the overall advertising performance of an advertising campaign, and standard demographic data.

Similarly to other social, communication, and marketing research, telemetric research has its limits apply to various areas, such as finance or technology, TV audience fragmentation, TV signal dispersion or a va- 
riety of alternative sources of TV reception, development of the Internet and mobile media tools, deficit of the TV viewers' attention in adverts watching, the difficulty in 'catching' TV viewers and keeping their attention, etc. The big issue, for example, of the whole Polish TV market is the tendency to keep up the numbers or to follow the rule of "the dictatorship of the ratings." Numbers determine programming decisions and this adversely affects the content of the TV programming in many instances. Such a quality of methodology and data is possible due to constant corrections of telemetric panels and telemetric procedures applied by the telemetric sector: the set of rules for the telemetric research reliability, called the 'Gold Standard.'

The development of telemetry aims to identify a passive viewer identification by the use of sensual techniques, such as fingerprints or eye scans. Many of these methods are currently tested. Therefore, a passive viewer identification project is the matter of the future. Additionally, new kinds of telemeters are better adjusted to the TV reality and the recent attempts to connect TV data with Internet data and Social Media (Big Data or AI approach). The system offered for example by the NAM on the Polish market is the first of its kind, as it combines digital, Social Media and TV audiences' behaviour, and content in under one common research system. Today, the people-meter measurement does not have any alternatives as far as more detailed and precise measurement is concerned. However, it should be adapted to the fast changing digital reality and embrace it as a part of the study requested by the media market.

Therefore, a study has been planned to contribute to the debate on TV features in general. In particular, it focuses on the TV audience measurement and evaluation systems in order to determine whether leading companies are reacting to the digital revolution in terms of TV research and how they handle the TV digital convergence. The focus on the TV audience measurement within the debate on the digital future of the TV cannot overlook the issue of an integrated measurement of digital, social or mobile TV. As pointed out, the limited presence of the perspective on the TV audience measurement in the context of digital convergence in wider communication studies makes the academic output les frequently rely on the professional insight, an insight which is important for determining a possible approach to evaluation and measurement of TV broadcasting and audiences now and in the future. 


\section{Methodology}

The main objective of the study is to determine the future of TV and TV research globally and particularly on the Polish media and broadcasting market in the view of growing digitalisation of content and audience behaviour.

In order to determine and describe the perception of telemetry professionals regarding the course of broadcasting digitalisation, a qualitative triangulated methodology has been applied. It combines the case study approach: focus on a TV research market leader and deep interviews with interpretative hermeneutics of qualitative data collection and analysis.

It starts with an extensive desk research of professional publications (professional, sectoral and company's own presentations, handbooks, guidebooks and reports) by TV and media experts regarding TV research development and future, apart from the theoretical insight into TV audiences.

Once completed, the case study approach focuses on a company representative for the telemetric sector, as one of the biggest media audience measurement companies operating globally (45 countries). The company is also distinguished by its innovative approach. The company has been anonymised for research purposes. The Polish market was chosen because of its significance on the East and Central European market: a switchover to Digital Video Broadcasting Terrestrial (DVBT) completed in 2013 , long history of TV presence dating back to the early 1950s, postcommunism broadcasting transformation and finally due to its growth. According to the $2018 \mathrm{PwC}$ report, the media market in Poland will increase by $3.5 \%$ in coming years, from EUR 9.15 bn at the end of 2018 to EUR 11.5 bn in 2022.

The research technique included five semi-structured online and offline interviews with company's experts and top management both from the global headquarters and Polish offices. Interviews, of 2 hours in duration, were performed in August and September 2017 in company premises or via Google hangouts and Skype with the company headquarters. The interviewees were selected on purpose in accordance with their top management functions, using the pre-existing contacts. It also followed the snowball sampling method to select competent directors of departments and high-ranked specialists. 
Open questions (23 in total) were organised in a random sequence and they referred to eight basic areas of interest, as follows:

1. State of digital measurement currently in short-term and long-term future

2. Challenges, obstacles and opportunities for digital TV measurement

3. Compatibility of digital and traditional TV measurement

4. Vision of digital TV measurement and TV future as mass media

5. Role of digital audiences in development of modern TV and its measurement.

6. Perception of market regarding digital measurement

7. Role of Big Data and any other technological developments in digital measurement

8. Social Media data and its role in TV measurement

Subsequently, data collected were anonymised, transcribed, and organised around each of 10 topics, followed by the structuring of the discourse and analysing it by means of interpretative hermeneutics, while looking for a meaningful insight.

Results showed a high level of expertise and professionalism of the company in tackling challenges of the Digital Era and its leadership in providing an adequate response to market needs at an early stage.

\section{Results}

5.1. The state of the digital measurement currently, and in short-term and long-term future

The total audience measurement is a unique option to combine the Internet and TV data, the passive and active types of consumption where the digital content and fragmented TV are converged to overcome the traditional division of measuring only sites online (online communities) versus the TV measurement oriented on content only.

It offers an integrated single stream of digital data (content and ads that are interrelated) together with standard TV (telemetric) data. A digital content consists of two different elements or patterns in consumption: passive TV (traditional) which still is consumed worldwide at the average level of 3-4 hours per day and TV-like content consumed online (informative sites) which constitutes more an active mode of content con- 
sumption. In general, online channels constitute a more active medium, since it presents a purpose of activity, usually the information search, e.g. Google browser. The digital content shall not therefore be considered only a video type of content since the majority of the online offer is based on the actively engaged information search. Obviously, the online content is composed of many platforms such as TV sites, TV online, or YouTube - considered as similar to TV and Netflix.

It is a basic company's framework composed of digital content ratings to measure effects of content consumption and digital ad ratings to measure the performance of a digital advertising campaign in a similar way to telemetry. Altogether, they deliver three basic variables: Reach, Resonance (perception) and Reaction of audiences (3R). The Digital Content Rating (DCR) and the Digital Ad Ratings, launched worldwide in 2016, started to offer a complete digital ad service in Poland. As described on the website, it is the key part of Nielsen's Total Audience Measurement of daily audiences which embraces all types of digital content (video and text alike), which offer the metrics compatible with TV metrics.

It is the next step after the Social Rating which is a solution added to standard GRP values and which measures the power of conversation on TV channels and programs on Twitter. The total measurement of audiences is possible due to compatibility and integrated measurement based on TV panel and Big Data. The data for digital ratings come from Facebook (users' data) and show the major precision comparing to other services, such as the one offered in Poland by Gemius, which are based mainly on estimations. As such, it does not have any competition on the market.

The methodology is based on a situation (event) context which includes tags in the ads and plug-ins in its content. The challenge here is to translate the situation into the panel's participants' behaviours and reactions. Data are anonymised and aggregated; online situations are then assigned to Facebook user data to assure continuity. Its major advantage is the capacity of identifying which panel gaps are the major drawback of that panel. In this way, Facebook data are combined together with ads and content data. Another method involves collaboration with agencies and media houses or other services in order to integrate their own data. The general idea is based on the Big Data philosophy, as for example the alliance with the Point Logical software in the case of the DAR. Due 
to this collaboration, data are introduced into a single system, e.g. only Facebook data of a single use.

The collaboration online and that with software providers to integrate both TV and digital data into one single source is the course marked in general by the Cross Media perspective.

In general, nowadays, the measurement is performed twofold. On the one hand, we have a traditional panel which is accurate and representative (based on sample), controlled and provide in-depth information. By means of the panel, measurement focuses on TV and TV online as well as video/static pages. The panel offers an independent research in terms of being free form the cooperation with online publishers. Nevertheless, since the online environment is large and fragmented, the margin for a measurement error is higher than in the case of the TV. Online behaviours are not determined by sex and age, and this coincidence is significantly more evident (demographic variables and actions) in the case of TV consumption. The online measurement requires cooperation with online publishers (embedded code). These two sides of the measurement are equally important to get a general audience picture. In order to capture and make these two worlds compatible, the SENSE service is used, which provides a sensitive volume of aggregated information regarding digital content and ratings - both ads and content form the base for digital data. As such, it is assigned to the panel. Additionally, upon the agreement with Facebook, the system provides anonymised and aggregated user data in order to detect online behaviours.

In the nearest future, the focus is going to be on further development of digital ad ratings on the Polish market, and the encouraging of clients to sign up for such a service. The goal is to turn this type of data into a new digital currency on the market. The second goal is to introduce the digital content rating on the Polish market within the effort to promote further integration of Internet and TV measurements.

In longer term, experts consider a modelling-based approach in which data from the panel, which detects consumers and viewers' profiles by means of valuable socio-economic data, will be integrated with digital data. As such, the further development of present Cross Media solutions will convert the output to aggregated data and information from the digital content.

The future might bring the focus on a targeted Smart TV as it has already been performed by SkyBox in Ireland or UK: this approach is 
based on dynamic ads concepts. This means that particular ads are broadcast depending on the historical TV viewing behaviour of the audience. Other questions for the future refer to the 30-days duration of cookies that limits digital research, shared devices and VOD like solutions to be used for advertising. The open question remains who should measure the digital TV and which system (hybrid, integrated, single source) would be the most appropriate.

5.2. The challenges, obstacles, issues and opportunities of TV measurement

\subsubsection{Challenges}

In terms of challenges, the main one is to get knowledge of the digital audience, computer users, which extends beyond cookies and is more focused on the understanding of digital behaviour instead. This will require further development of methodology implemented with Facebook that constitutes a mega research panel that monitors individual user accounts and therefore is able to monitor their real behaviour. The point is to understand and predict them. Generally speaking, the challenge is the methodology to bring together TV, online TV and digital content. Therefore, the challenge is strongly related to the Cross Media approach in order to make digital information usable across media space.

Another challenge, with no less significance, is to measure audiences across different platforms in a similar way - with the aim to create a common market standard with compatible variables and measurement systems. Unlike Facebook and other systems, Google has rejected the possibility to participate in such kind of measurement. Therefore, the challenge is to establish a modern system based on a feed model (websites and online services) rather than a classic user model. The methodological challenge is to integrate digital and traditional televisions and to establish a foundation for a common methodology and set of variables, statistics and metrics, which would be comparable across various channels.

Additionally, another challenge is to further develop and modify the current classic model based on the unique user and replace it with a new 
programmatic measurement model. Challenges to digital measurement also include fraud (panel is immune to falsification) and viewability issues (whether content is really seen/viewed when appear in the screen).

Apart from methodological and organisational challenges, financial challenges are equally important, especially the investment in advertising. Four years ago, digital media experienced a big financial influx of investment. However, examples of last year show that companies, such as $P \& G$, are gradually giving more importance to $\mathrm{TV}$ as the more accountable channel. Another example is Facebook which over-estimated advertising efficacy.

The human factor as a new challenge should not be ignored either. There is an increasing need to understand human digital and TV behaviour beyond mere measuring of the output. This requires to shift research questions from what users do to why they watch and consume certain content, taking into consideration the aforementioned division determined by a distinctive media nature: passive versus active.

In summary, the challenge is to build an advanced system that can measure the same data in the same way across all media, and multiple media platforms and formats.

\subsubsection{Opportunity}

The main opportunity is business development towards the measurement across all platforms and its transparency. The clients prefer to use their own data instead of independent measurement figures, especially provided by editors. The opportunity is to offer a digital measurement as an additional service to the traditional TV audience measurement for both editors and advertisers.

Therefore, the opportunity is to integrate these two types of measurement and create total audience data as a Holy Grail of advertising taking into account that more than $80 \%$ of advertising investment goes to the TV and the Internet. This refers mainly to the Polish market, since such solutions are already implemented in the US, France, and in the UK where a post-hoc analysis of particular campaigns is already offered. So far, the lack of infrastructure on the Polish media market may hinder the development.

The other opportunity is to develop a methodology for the integrated and common measurement of all platforms in a uniform way. It is 
particularly relevant for Polish mobile services, since they constitute more than $50 \%$ of the entire market. Yet another opportunity is to develop a technology which is capable to recognise if the content has been consumed by one or two persons (common computer and Unique Users methodology) or to be capable of determining whether one or two people watch TV and simultaneously surf on the Internet. Therefore, the opportunity lies in providing multiple solutions instead of a single one to integrate the panel and senses systems with the overall aim to harmonise them in terms of metrics and methodology. Furthermore, it can provide a possibility to demonstrate the digital value, when it does not correspond with the content.

Other opportunities are to create a hybrid solution (Sense with a panel) to balance in the best possible way the cost and accuracy of both types of measurement (traditional TV measurement is considered expensive due to fragmented viewing but easy to measure even with time - shift issues, although overall ROI is considerably low). The hybrid solution provides the market and sector with the access to all and the same data in a uniform way. This helps to build a transparent practice. In summary, a common denominator for the metrics operative in both systems, independent source of data and integrated methodology are the three most important opportunities for the sector.

\subsubsection{Issues and obstacles}

The 50 years of the development of the television created a common standard that all parties subscribe. As a matter of fact, the medium itself has not changed much since its early days. As far as the Internet is concerned, there is no general agreement regarding standards and the Internet as a medium is undergoing a continuous transformation. There is no general market consensus on the standards of measurement of the Internet activity, especially in services of low reach and ratings. The current issue discussed internationally is related to comparable and compatible metrics. Additionally, the digital measurement involves a number of issues and different approaches. Similarly, the sector is fragmented in terms of research. Modalities of measurement are a mixture of TV and digital, or only one type of measurement but applied differently, some alternative partial solutions or none of the above. The digital measure- 
ment struggles to achieve effectiveness hampered by inefficient ads and poor algorithms. These drawbacks are hindering its development. Furthermore, the Senses which measure the content require a technical and methodological solution to recognise what people are actually consuming and who these people really are (who watches what).

The sector is not free from ethical concerns. Digital solutions are mainly developed to measure advertising so online service owners are interested in demonstrating their capacity of reaching attractive targets and implementing effective campaigns. The ethical side, like in the case of overestimated Facebook, focuses on demonstrating the impact in terms of advertising investment (ROI). The ethical conduct in the future development of digital media will require a significant level of transparency and accuracy.

Finally, both types of measurement need to address fragmented ads and viewing issues that characterise the digital and TV, respectively.

As far as obstacles are concerned, it is worth to mention those related to the creation of an all-platform meter, which is not only difficult technically and methodology-wise but also quite expensive.

\subsection{The compatibility of digital and traditional TV measurements}

As such, ratings of TV and digital have not been compatible until now. One is based on panel's participants and another on a Unique User (UU). The main variables in digital are those imported from the TV standard Reach, (TV) Frequency and GRP in the targets. Therefore, the digital TV is adjusted to the TV structure and not the other way round. Other measures include: Time spent, Spots, Impressions, GRP in general and variables related to cost: Cost per GRP, Cost per Point/Impression. They are similar in general terms to the Cross Media approach. It is worth to mention that the CTR has been coming back to the digital measurement.

The compatibility is aimed at providing the possibility to compare effectiveness and profitability in two different media. There is no general need or pressure for new indicators or special variables but rather for the course of action that makes digital compatible with TV for example in case of viewability. It is necessary to verify if the ad has been indeed served in the screen - viewed by Unique Users (viewability), since 60\% 
of ads remain unseen and therefore invisible for users even though they represent more than $80 \%$ of advertising income.

For the time being, indicators from both sources are not compatible. Nevertheless, standards from TV, being far less complex medium, are implemented into the Internet in order to facilitate compatibility by means of special research techniques. Those, on the one hand, enable compatibility but, on the other, the measurement is performed at the cost of innovation. The effort to make these two compatible drives towards simplification of the far more complex digital sphere. TV and digital are measured separately, and the digital environment is far more innovative than the TV. This means that the more innovative medium, the more difficult it is to adjust it to TV standards. Furthermore, variables, methods and standards commonly accepted in the case of TV raise doubts and concerns when applied to the Internet. The sector looks for an outstanding quality of the digital measurement where the digital is equally important to the TV measurement.

\subsection{The vision of digital TV and digital measurement}

The visions are probably the most pluralistic. Some believe that the classic TV, as we know it nowadays, will disappear, others declare the opposite. Regarding the first group, there is a common belief that TV will transform into "a computer on the wall" that provides an innovative type of entertainment: more interactive, totally on demand and personalised, based on social recommendation and behaviour algorithms based on data (similar to Youtube model: suggestions that analyse historical preferences and viewing behaviour). This will be the modern kind of TV without channels and producing their own content, similar to the Netflix model. Although entities operating on the market and content may remain the same, both forms to reach the audience and the viewer profile will change. Regarding the first vision, this revolution will come quickly and will happen very fast, especially if national regulations stimulate it by blocking and controlling the content or establishing censorship in the Internet. In general, the first vision of the TV revolution predicts a significant change in consumption patterns for TV and the Internet. Therefore, it is rather a revolutionary vision in which digital behaviours take over the traditional TV medium and change it totally. This vision claims that 
a model of paid content is quite realistic. However, there is a common belief that it will happen on a small scale as it is dangerous for online editors. It is especially true in Poland where the tendency to pay for the content due to certain economic conditions is quite limited.

On the contrary, the second vision predicts that changes will be slow due to the lobby of older users who account for a significant consumption of the contemporary TV. This vision supported by some management board members also emphasizes that, contrary to the common belief, the TV consumption among younger users is not that large, and ratings indicate a stable tendency throughout the years. The convergence of these opposite visions demonstrate that consumption patterns will or might change significantly. However, the softer vision of slow of TV remodelling is based rather on the collaboration of these two media in the next $10-15$ years forced by the market and consumers. It is a process that will take place over decades due to the technological gap among elderly and low income segments of the audience. Eventually, the Internet will dominate but rather as the result of a slow evolution of content towards more simplified forms, due to the aforementioned demographic characteristics, and consequently, the content will cause the change in consumption patterns.

Therefore, we expect two quite opposite visions of TV and digital development in the future: revolution versus evolution.

It is also worth to mention a more consensual vision that is situated between these two. According to that vision, the contemporary TV will not change significantly. The live events will remain, like news, sports and shows, including launches of new series and seasons. The main advantage of TV consumption is its live and real-time character, especially in the case of different types of TV shows. This real time and live character of events will bring us back to the behaviour typical for the traditional TV: the ability to gather people together in front of the screen. Meanwhile, the digital TV will simply disseminate its content on different devices but this new TV will remain traditional as far as behaviours are concerned. Additionally, we can expect further fragmentation of the market as new players such as Amazon, Netflix and similar try to transform the digital TV and digital content into more cost-effective services. The future TV will have to face the issue of cost versus quality but the general course is that TV and digital will eventually merge and blend. 
The development of the digital measurement will take place alongside and according to the general development of the digital sphere. The overall aim is to be able to measure it across all platforms and devices by means of common denominators in order to assure compatibility.

An important dimension regarding the above is of a political nature. Policy changes will stimulate minor changes in measurement and those might cause major financial changes (in terms of both investment and profit).

So far, we have observed attempts to achieve the goal by using different approaches and perspectives. The fragmentation of efforts, services, software providers and the lack of general collaboration is remarkable: each company and provider acts in their own way and separately (Google, telemetry) but similarly to Youtube. It is necessary to develop the gold standard already at this stage.

5.5. How does the market see the opportunity for a digital measurement

As far as the development of the digital measurement is concerned, the Polish market remains behind the UK, France, the US and Germany. However, this does not apply to advertising investment. In general, Central Europe does not demonstrate the same level of advancement as the West, although the development of digital platforms and their usage follow worldwide trends. In terms of investment, the biggest advertisers focus mainly on wealthier markets of Western Europe. Therefore, a natural demand has developed for better standards in measurement and evaluation of effectiveness. Additionally, it seems that ethical standards in research are more significant in Western than in Eastern Europe.

Officially, the Polish market demands transparency and an independent research provider. However, online services and editors with low ratings and reach do not want to facilitate this kind of measurement to avoid having their weaknesses exposed. As the measurement of digital media requires the cooperation between digital content providers, it becomes the question of the attitude towards such a collaboration. The market has reacted in a positive manner towards a more detailed and accurate DAR offer that is competing with the offers of Gemius and other services which made the market quite chaotic in terms of measurement and research services. 
5.6. The role of Big Data and other technology developments in digital measurement

Big Data will definitely lead to the revolution and play a key role in the transition from an individual panel towards a Big Data approach. The over presence of data and the overflow of information will result in the establishing of research agencies that will transform into big analytical centres examining specific indicators rather than catering for needs of data owners and producers. Research companies might try to collect data (Big Data) by means of programmatic and retargeting models, becoming the competition for marketing companies. Similarly, Nielsen heads towards advertising and marketing services by using the recollected Big Data for selling the marketing services. Senses research service, for example, it is built on Big Data philosophy being Big Data a key point in digital and TV measurement nowadays.

\subsection{Social Media and its role in TV audiences' measurement}

As such, Social Media ratings is a real-time measurement providing real-time ratings which monitor shared and earned content on different social networks, such as Facebook, Twitter, etc. (total reactions of the users: comments, likes, retweets, replies, memes, interactions, as provided by statistics of those social networks and typical for Social Media reality). As it is commonly known, Social Media demonstrate the scale of engagement on TV and Netflix alike. Additionally, it provides a valuable information regarding the word-of-mouth and virality dimensions. The highest levels of engagement can be found in live shows broadcasts. In spite of this viral value and fans' implication insight for the purposes of shows attractiveness indicators, Social Media data are rather secondary and not demanded and they should be treated separately to the traditional TV measurement. In spite of big boom in Social Media and general social networks explosion, the Social Media data are complimentary and as such do not revolutionize the way TV is measured or broadcasted. It might one day show its utility when developing the technology able to offer the discounts to Facebook fans watching a particular show, but this requires further advancement in targeting. The market as a whole uses Social Media Ratings as the additional source of data. However, key decisions are 
formed on the basis of TV ratings. Some marketing decisions, such as the packaging, are oriented through Social Media data, being therefore a helpful insight for the market and treated as such by the clients. It is definitely the additional, complimentary and secondary source of data that serves occasionally to measure emotions of audiences or virality purposes.

The questions regarding the role of Social Media in the modern TV measurement have been considered from different perspectives. On one hand, we have the attempts to create a common measurement for digital and TV which is characterised by the same ratings and methods across all the platforms. On the other hand, there are already services as the one of Nielsen (Social Media Ratings) that offers the telemetric data of one particular programme plus Social Media engagement regarding this particular show. Something similar known as Social Media Monitoring is the element of the Insight service offered by McKinsey.

Social Media Ratings have not replaced the traditional TV ratings but have not entered the buying circle. Indeed, Social Media ratings are not even included in the Cross Media services.

5.8. The role of digital audiences in the development of the modern TV and its measurement

There is a common prediction on the possibility of creating oligopoly based on the alliances between the biggest and most powerful media players of the sector for example Facebook with Samsung as the merge of technology, service, contents and TV as the medium. This will allow the total measurement of TV audience behaviours. For example, cameras in TV devices by Samsung (Samsung already measures audience in its TV screens) and Nielsen's audiometers. As such, the first major shift is the alliance and collaboration between one of the biggest global telemetry providers and Facebook that has created the biggest data base of users and media content/TV data based on Big Data technology which enables to measure both: TV viewership and online behaviours. Another big thing could be a thermo-vision and thermo-active measurement of viewing behaviours on screens of different types. The biggest changes will also include and incorporate Big Data services and Cross Media advancement.

According to experts, TV as the screen will slowly disappear from our walls as a traditional device but TV would persist, as the UGC 
would not become the only source of content. The reception of TV will change with the particular focus on the audience as the active consumer of content e.g. news online would be published in the form of the blog. $\mathrm{TV}$ as the traditional device would transform towards the device that manage the house electronically (smart house). Multi-platform broadcasting will bring the total lack of limits regarding the formats available for consumption.

According to another interviewed expert, the digital will not kill the traditional TV content or Netflix. Digital content is fairly static and video shall be considered more in terms of TV type of content than digital one. Netflix, for example, is similar to traditional TV but joins various modalities: digital, VOD and traditional TV, being the service on the borders of traditional division. However, it shall not be considered revolution but rather the additional TV source. In these terms, the method of content delivery and broadcasting may change, but the way people watch TV and video content will remain.

\section{Conclusions and discussion}

According to the interviewees, two almost contradictory tendencies have been observed. The first tendency is the coherence and integration. The TV measurement will eventually overtake the digital measurement in terms that the digital ratings will be added to TV ratings. The second one is the fragmentation and emergence of new smart platforms of TV broadcasting and the increasing number of formats and platforms. The convergence and make these two systems comparable and compatible is the way of the further development marked by Cross Media perspective, fights for ethical conduct of the sector, anti- fraud measures, methodological, financial and technical issues. In overall terms, the TV is the standard here to make the digital measurement similar to the established, independent, transparent, accurate and trustable system.

First of all, TV as the medium and content, as well as the consumption behaviour is attractive for big digital players such as Facebook and Google who will like to begin making profit on these type of contents in the form of TV like content or even creating their own TV. Furthermore, there is an observable process of TV change towards multimedia platforms and the convergence of contents, formats and media. As such, 
it will be expected the further merges between big media players. Therefore, the perspective is very dynamic and open. Hereby, it is observed a certain dualism however the general objective is to control each one's piece of pie. On one hand, TV wants to measure digital and become more digital to control this environment and make more profits. The digital players on the other hand want to become comparable with TV gold standards of measurement.

For the time being, these are two separate worlds. TV research is independent since it does not require the cooperation from editors while digital needs to collaborate with big providers of content such as broadcasters and publishers, e.g. Facebook or Google. Currently, digital is syndicated and there is no unique solution proposed in terms of cooperation among the online players and media research companies, bearing in mind the principal aim of digital to be focused mainly on advertising. Whereas digital has been so far experiencing a big boom in terms of advertising investment, the independent and accurate research constitutes the gold standard in TV measurement, usually overlooked in the digital.

Thus, the opportunity lays in the common measurement for both TV and digital as well as the development of the technology that will provide a reliable and compatible digital measurement. There is no consensus regarding the direction of this development: fraud, viewability standards and issues might be pivot here. There is an important role of multiple market organisations and clients who validate the cost-effectiveness and efficiency of such technology as well as service applied to Internet. The ROI is probably the biggest issue here. Almost all concerns are focused on the compatibility of TV and digital: the common indicators that measure the same thing in different media in the same way and the same dimensions. The overall need and business aim to control some part of digital and TV market simultaneously causes the emergence of new stakeholders that are forced to find the new ways of collaborations meaning it is unavoidable that these two worlds would start to work together and converge at some point.

Regarding the modern telemetry provider as the main object of this case study, its leadership in providing the TV measurement technology that embraces both standard and digital TV is evidenced throughout the interviews' data. The corporation, both in Poland and globally, highlights its principle orientation to build the market standard that includes digital. 
The company has a very strong position and on many occasions is the only provider of TV data on the market. Nevertheless, rather surprisingly, according to the perception of the management, it is not perceived as the innovative organisation in terms of TV measurement by the rest of the sector. As far as the digital measurement is concerned, the brand has been successfully created and the new product has very positive perspective ahead although with some limitations that are unavoidable at this stage of digital development. In terms of the future of digital TV measurement, the interviewed company seems to be few steps ahead of the market with its innovative approach and very strong orientation towards the new technologies. However, its rollout of the company's philosophy may vary from market to market and its application demonstrate various degree of advancement. Sector-wise, companies in the forefront of the modern telemetric sector have managed to build the service free of fraud that usually characterises the digital measurement. The sector tends to buy the product and service they can trust and the one established as the market standard. In this dimension, Nielsen has managed to reach the point.

The general direction of the sector of TV audience measurement and the market is the convergence and overall fusion of different sources of data: Big Data, panels, etc. All the subjects operating within the scope of media research follow this direction of the measurement service's development. Big Data and Cross Media is the overall direction of the further development of TV and digital measurement.

As such, the study has allowed obtaining a valuable insight into the biggest TV research provider globally and confronting it with the local market views (Poland). The qualitative method triangulated into case study focused on a global leader and with the help of semi-structured interviews, helped to collect the meaningful professional opinions based on the expertise and to build the global vision on the topic. The future of TV research in terms of digital convergence embraces the technological development and is full of challenges and obstacles to face. The market needs, provoked by digitalisation, change in a fast-paced manner so the digitalisation of the measurement must follow solid development of market and company standards and research products that clients can trust. The professional perspective included into academic research offers a wider approach to the changes and permits keeping the science with the changes of the market. 
The next step for the study would be to confront views of the company with the other providers and operators on the TV research sector, as well as with the rest of the media market by means of qualitative research that offers more insightful analysis than the opinion survey.

\section{Bibliography}

\section{Books:}

Abelman R., Atkin J. D. (2000), The Televiewing Audience: the Art and Science of Watching TV, Hampton Press, New Jersey.

Ang I. (1991), Desperately Seeking the Audience, Routledge, London.

Ettema S. J., Whitney D. C. (ed.) (1994), Audiencemaking: How the Media Create the Audience, Sage Publications, London.

Goban-Klas T. (1999), Media i komunikowanie masowe. Teorie i analizy prasy, radia, TV i internetu, Wydawnictwo Naukowe PWN, Cracow.

Godzic W. (2002), Telewizja jako kultura, RABID, Cracow.

Jensen K. B. (ed.) (2002), A Handbook of Media and Communication Research: Qualitative and Quantitative Methodologies, Routledge, London.

Mrozowski M. (2001). Media masowe. Władza, rozrywka i biznes, Oficyna Wydawnicza Aspra, Warszawa.

Sztabiński P. B., Sztabiński F.; Sawiński Z. (ed.) (2001), Nowe metody. Nowe podejścia badawcze w naukach społecznych, IFiS PAN, Warsaw.

\section{Articles:}

Gallego F. (2013), Social TV Analytics: nuevas métricas para una nueva forma de entender la comunicación, "Index Comunicación", no. 3, pp. 13-39.

Segado F., Grandío M., Fernández-Gómez E. (2015), Social media and television: a bibliographic review based on the Web of Science, "El Profesional De La Información", vol. 24, no. 3, pp. 227-234.

van Es K., van Geenen D., Boeschoten T. (2015), Re-imagining Television Audience Research: Tracing Viewing Patterns on Twitter, "Media Culture Journal", vol. 18, no. 6, pp. 1-10, http://journal.media-culture.org.au/index.php/mcjournal/article/ view/1032.

\section{Professional press publications:}

Baym K. N. (23.09.2013), Data Not Seen: The Uses and Shortcomings of Social Media Metrics, "First Monday", 18.10, http://firstmonday.org/ojs/index.php/fm/ article/view/4873/3752, 30.08.2017.

C-Scott M. (21.05.2015), Television is changing, and viewer metrics need to change with it, The Conversation.com, https://theconversation.com/television-ischanging-and-viewer-metrics-need-to-change-with-it-41758, 30.08.2017. 
DiGiorgio L. (07.07.2017), The Future of TV Metrics, TV Technology.com, http:// www.tvtechnology.com/opinions/0004/the-future-of-tv-metrics/281342, 28.08.2017.

Green M. (31.08.2017), It's Time To Apply Digital Video Metrics To TV Ratings, Mediapost.com, https:/www.mediapost.com/publications/article/306667/itstime-to-apply-digital-video-metrics-to-tv-rat.html, 15.09.2017.

Kohn K. (28.07.2017), Problems with TV Measurement, BroadcastingCable.com, http:/www.broadcastingcable.com/blog/bc-guest-blogs/problem-tv-measurement/166875, 28.08.2017.

Steinberg B. (11.04.2017), TV Industry Struggles to Agree on Ratings Innovation, Variety.com, http://variety.com/2017/tv/features/nielsen-total-content-ratings-1202027752/, 30.08.2017.

\section{Internet:}

National Council for Radio and Television Poland (2017), http://www.krrit.gov.pl/ dla-mediow-i-analitykow/nowe-technologie/, 16.09.2017.

Nielsen Audience Measurement (2017), http://www.agbnielsen.pl/; http://www.nielsen.com/eu/en/solutions/measurement/audience.html; http://www.agbnielsen. com/, 08.09.2017.

PricewaterhouseCoopers International Limited (2017), Digital IQ 2017, https://www. pwc.pl/pl/publikacje/2017/digitaliq2017.html, 16.09.2017.

Polish media market value to rise by billions in five yrs: report, 16.10.2018, https:// polandin.com/39493231/polish-media-market-value-to-rise-by-billions-infive-yrs-report, 30.10.2019.

PwC (2017), Doing business in Poland Report, www.pwc. com https://www.pwc.pl/ $\mathrm{pl} / \mathrm{pdf} /$ doing-business-in-Poland-report-2017.pdf.

Raport Mobile (2018), Mobile vs inne media, https://iab.org.pl/aktualnosci/raportmobile-2018-mobile-vs-inne-media/

Szostak S. (2013), Poland's Return to Europe: Polish Terrestrial Broadcasters and TV Fictiont, https://www.viewjournal.eu/articles/110/print/.

\section{Szanse i wyzwania konwergencji cyfrowej telewizji: pomiary widowni w erze komunikacji cyfrowej}

\section{Streszczenie}

Badania rynku telewizyjnego i widowni były dotychczas zdominowane przez system telemetryczny, który współpracuje z panelem w procesie badań longituidalnych. Jednak rozwój ery cyfrowej naznaczony rosnącym zużyciem treści audiowizualnych i telewizyjnych w Internecie lub za pośrednictwem systemów VOD, usług subskrypcyjnych, transmisji itp. zmienił sposób pomiarów widowni telewizyjnej prowadzonych w celu uzyskania danych znaczących dla reklamodawców. Usługi cyfrowe, 
a zatem konsumpcja reklam internetowych, zmusza firmy telemetryczne do wprowadzenia zmian $\mathrm{w}$ metodologii $\mathrm{i}$ usług pomiarowych $\mathrm{w}$ celu wyeliminowania problemów metodologicznych i kwestii statystycznych, jakie pojawiają się w Internecie. Badania telewizyjne w dobie cyfrowej wymagają nie tylko nowych metod pomiarowych i przykładowych projektów lub innego planowania badań, ale także muszą stawiać czoła nowym wyzwaniom i wymaganiom dotyczącym aspektów technicznych, jak również aspektów społecznych i ekonomicznych. Wskutek tych tendencji, interesującym zagadnieniem jest zbadanie jak era odbiorców telewizji cyfrowej zmienia sposób projektowania i wykonywania usług telemetrycznych na całym świecie i na rynku polskim. Badanie zawarte w tym artykule ma na celu odkrycie, w jaki sposób usługa pomiaru widowni telewizyjnej reaguje na zmiany spowodowane digitalizacją, jakie wyzwania i wymagania należy spełnić, aby rozwiązać problem cyfryzacji rynku telewizyjnego w zakresie planowania badań i metodologii, a na koniec jak światowy i polski rynek postrzega usługi oferowane przez sektor telemetryczny. Badanie obejmuje serię indywidualnych, częściowo ustrukturyzowanych wywiadów online z menedżerami i zarządami firmy reprezentującej badania telemetryczne, a także z działem cyfrowej oceny reklam w Polsce i centrali w Szwajcarii. Wyniki pokazują kluczowe zmiany, szanse i wyzwania wynikające z cyfryzacji konsumpcji telewizyjnej zgodnie z percepcją rady dyrektorów, a także strategię firmy na rzecz konwergencji cyfrowej i wreszcie oszacowanie potrzeb nowych rynków oraz odbiorcy w trakcie transformacji cyfrowej.

Słowa kluczowe: telewizja, widownia telewizyjna, telemetria, pomiar widowni telewizyjnych, cyfryzacja, era cyfrowa 